\title{
Introduction: Lebensraum and its discontents
}

\author{
Ian Klinke (University of Oxford) and Mark Bassin (Södertörn University) \\ Journal of Historical Geography
}

This special issue grapples with a text that stands at the inception of modern geo- and biopolitics - the 1901 essay 'Lebensraum: a biogeographical study' written by the German geographer Friedrich Ratzel (1844-1904). In this essay, the trained zoologist and founding father of modern political geography set out a theory of the world in which humans and their social institutions are but an effect of the natural world and therefore subject to nature's laws in much the same way as the animal and plant kingdom. Although Ratzel describes his essay as primarily written in the language of biogeography, he uses it to flesh out his conception of the state as an organism that struggles for Lebensraum (living space). The arguments Ratzel develops in this essay should be read as an attempt to draw on basic Darwinian ideas to account for the expansive tendency of late nineteenth-century imperialism and state competition. By treating historical and biological processes alike, Ratzel famously came to naturalise both the territorial configuration of world politics and the phenomenon of interstate war.

Whilst already a notable academic figure during his lifetime, it is especially the posthumous career of his Lebensraum concept that has made Ratzel a continued object of fascination for geographers, historians and political scientists alike. Indeed, Ratzel remains something of a disgraced figure in the geographical canon today, given his reputation for environmental determinism and his influence on interwar politics. Indeed, it was one of his followers, the geographer Karl Haushofer, who claimed to have introduced Adolf Hitler to the idea of Lebensraum as the latter was cobbling together his 1925 book Mein Kampf in Landsberg prison. ${ }^{1}$ It is thus difficult to understate the historical significance of Ratzel's Lebensraum concept, even if his essay's immediate readership would have been limited to academic circles.

And yet, this special issue suggests that Ratzel's text is perhaps not 'merely' of historical interest, but of theoretical significance too. For whilst geopolitical ideas were mushrooming elsewhere too in the nineteenth century, Ratzel's work is unusual in its biogeographical understanding of the state as organism: a political life form that tries to secure its survival by conquering and defending space. It is the primacy of life within his political theory that links Ratzel to a range of ongoing theoretical debates on the nature and emergence of modern biopolitics - the politics of life - even though this connection has not yet been significantly explored. ${ }^{2}$ Moreover, Ratzel's essay embodies and promotes what we would today undoubtedly call a 'more-than-human geography' that tries to bridge the divide between science and philosophy and takes off from an understanding of the human as an effect of the natural world. ${ }^{3}$ Indeed, Ratzel's entire oeuvre rests on the fundamental assumption of the unity of life and earth. Life, he is never tired of repeating, is earthbound.

Despite the fact that there has been a significant and continuous intellectual debate on Ratzel, which has included biographical work, ${ }^{4}$ explorations of Ratzel's place within nineteenth-century German colonial imaginaries, ${ }^{5}$ examinations of his role in the history of geopolitical thought, ${ }^{6}$ as well as work on his Lebensraum concept itself, ${ }^{7}$ it is notable that, with only few exceptions, ${ }^{8}$ Ratzel's major works have not been translated into English. This is perhaps surprising given the rising interest in other German spatial thinkers such as Carl Schmitt and Walter Christaller.9 We argue that if future generations of Anglophone geographers and historians want to understand the popularisation of Lebensraum as a political concept, they will have to read this text and come to terms with Ratzel's conceptual universe. 


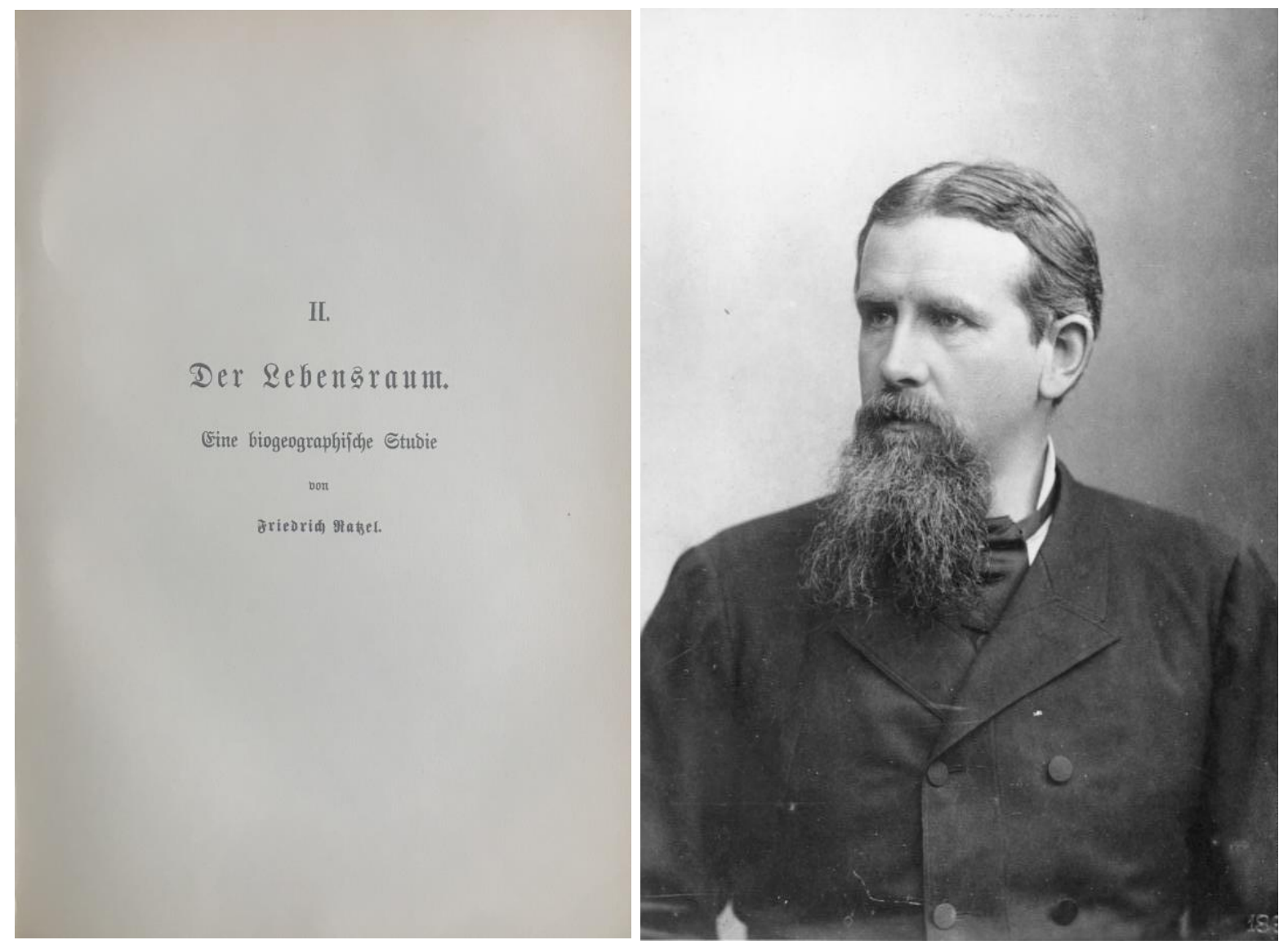

figure 1 Ratzel (1901) Der Lebensraum titlepage, figure 2 protrait of Ratzel (taken between 1890 and 1904)

\section{Life and work of a more-than-human geographer}

Friedrich Ratzel was born in 1844 in the grand duchy of Baden in what is today southern Germany. He left his parents' house at a tender age of fourteen to be trained as a pharmacist, an experience he would later describe as traumatic. Having always felt a curiosity for the natural world, Ratzel was unhappy with the prospect of life in the pharmacy and would, after some hesitation on his parents' side, convince them in 1866 to let him study zoology and geology instead. Spending time in the universities of Heidelberg, Jena and Berlin, Ratzel came under the influence of the ideas of Charles Darwin, whose The Origin of Species had recently been translated into German. He was also inspired by the biologist and philosopher Ernst Haeckel whose lectures the young Ratzel attended. After completing his thesis in 1868, Ratzel spent a couple of years working as a research assistant and journalist before volunteering to serve in the 1870-1871 Franco-Prussian war, during which he was wounded and forced to recover in a military hospital.

Upon his release, Ratzel embarked on a number of expeditions to the Americas, working as a travel writer and journalist, a period described by Carl Sauer as formative to his worldview. ${ }^{10}$ Thereafter, he returned to Germany and took up a position at the University of Munich in 1875 , where in 1880 he was promoted to a professorship in geography. Six years later, Ratzel moved to Leipzig where he worked until his death in 1904. It is during this final period that he published his most notable books, including the 1897 Politische Geographie ('Political Geography'), the second volume of Anthropogeographie ('Human Geography', 1882 
and 1891), the second and third volumes of Völkerkunde ('The History of Mankind', 1885, 1895 and 1888), his 1902 book Die Erde und das Leben ('The Earth and Life') and his 1901 Lebensraum essay. A prolific writer, Ratzel moved through different intellectual phases in his career. Beginning with biogeography, he then turned to travel writing, anthropology, human geography and political geography, even autobiography, before returning to biogeography shortly before his death in 1904 .

Despite the plethora of genres and disciplines that his work engaged with (and managed to shape), his oeuvre is not as diverse as it might appear. Rather, it coalesces around a number of key themes and arguments, including most prominently the influence of geology and climate on history. Whilst much of Ratzel's motivation was scientific, he was also an intensely political scholar. Not only was his work concerned with the state (as organism), but he was also willing to make his voice heard beyond the academy. Having fought in the last of the German unification wars, Ratzel was a keen nationalist who was, for a while at least, a member of the radical conservative Pan-German league (Alldeutscher Verband) and the equally influential German Colonial Society (Deutsche Kolonialgesellschaft), which continuously lobbied the German empire to establish colonies more proactively. Regarding Europe as a politically saturated space, Ratzel advocated colonialism in Africa as the only way in which the German nation could find new living space. Ratzel had already adopted a colonial imagination at an early stage, as his travel and ethnological writings reveal. Not only did he describe the black population in the United States as subhuman and in need of resettlement, but he was also willing to suggest that slave labour was but a necessity of certain climatic conditions."

Ratzel was a firm believer that war was a natural condition of world history and it therefore does not come as a surprise that he never spoke a critical word about the war that left him an invalid. In fact, his experience of the Franco-Prussian war prompted him to note at the end of his life that it was 'a shame that there are not more wars'. ${ }^{2}$ Fantasising that the German navy would one day rival that of the British empire, Ratzel was considered one of a number of 'fleet professors' who enthusiastically promoted naval expansion in the final decades of the nineteenth century. ${ }^{13}$ Although Ratzel's nationalism, militarism and support of colonialism mark him out as a nineteenth-century radical conservative, he was in other ways perhaps ahead of his time. Ratzel was neither anti-Semitic nor particularly misogynistic. He also dismissed the biological racism of Houston Stewart Chamberlain and Arthur de Gobineau ${ }^{14}$ and argued against racial purity and for migration as a process that makes social groups more competitive. It is thus perhaps somewhat puzzling that contemporary figures in the German new right have adopted his ideas as part of their anti-migration agenda. ${ }^{15}$

Ratzel thus remains an ambivalent and contentious figure whose intellect often made him veer towards ideas that would become radicalised to detrimental effect after his death. It is his political geography in particular that continues to find him friends amongst neo-fascists like the Russian Eurasianist Aleksandr Dugin. ${ }^{16}$ And yet, this very same intellect also led to the production of some very thoughtful and nuanced work, particularly in his final years. Disillusioned by the way in which specialisation and disciplinary boundaries restricted scholarly debates, he argued for the integration of science and the humanities. Indeed, by the end of his life Ratzel had become convinced that science had its limitations and that geography had to borrow from art and philosophy if it wanted to understand the world in a more comprehensive way. Ratzel's final project, a biogeography in which human society was but a chapter, remained unfinished. ${ }^{17}$ But it is in the Lebensraum essay that we can glimpse the contours of this project.

\section{Lebensraum: A Short Begriffsgeschichte}

While Ratzel certainly offered the most comprehensive formulation of Lebensraum, he neither invented the term nor even originated the concept. To the contrary, his thinking was anchored in nineteenth-century debates in the natural and social sciences about the dynamics 
of the relationship between human societies and the external environment. Two perspectives in particular were significant for him. The first was the argument that geographical conditions were not passive but rather played a direct role in shaping human activity. By the 1870 , the ethnographer Oscar Peschel had already used the term Lebensraum to denote the specific natural region in which a particular people had emerged and developed. Peschel maintained that there was a clear causal connection between land and people, in the sense that the latter 'adapted' to the conditions of their local habitat. The influence of the external environment could be either positive or 'unfavourable' (ungünstig) for social development and progress. ${ }^{18}$ Some years later, the geographer and cartographer Richard Andree also used the term, and indeed in the same ecological sense. Yet while Andree did not question the significance of external environmental influences, he argued nonetheless that they were on the whole less important for shaping the characteristics of a people than in-born qualities of genetics and race. ${ }^{19}$

The second perspective similarly involved the relationship between natural regions and the human societies that inhabited them. However, in this case the focus was on the insuperable disjunction between the constant growth of human populations on the one hand and the natural limitations of their respective geographical habitats to provide the sustenance necessary to sustain this growth on the other. In his famous treatise on population, Thomas Malthus had repeatedly called attention to the imbalanced correlation between 'room and nourishment', as he put it, and he indicated how - if unchecked - 'this perpetual struggle for room and food' would eventually and necessarily trigger major conflicts. 'The redundant inhabitants' of an overpopulated region, he explained, would not be able to 'find room for themselves without expelling their nearest neighbors ... which would necessarily give occasion to frequent contests'. ${ }^{20}$

Using a similar logic, Moritz Wagner, a noted German naturalist who was also Friedrich Ratzel's teacher and mentor, sought to elaborate Darwin's theory of evolution, although unlike Malthus Wagner drew his evidence from the plant and animal kingdoms and not human demography. Yet where Malthus famously insisted that the tension could be neutralized through social controls on population growth, Wagner assumed that growth was as natural as life itself and neither could nor should be limited. The necessary consequence was an irresistible natural impulse for all organic life to seek new spaces to occupy and colonize. Movement and migration were the most fundamental principles of all organic life and represented a vital part of the evolutionary process. ${ }^{21}$

The nuances of Ratzel's own complex formulation of the Lebensraum concept are analyzed in the commentaries that accompany the present translation, and there is no need for additional discussion here. ${ }^{22}$ Suffice it to say that his understanding of Lebensraum combined the two perspectives just described: the causal interconnection between people and land on the one hand, and the fixation on movement as an essential natural imperative driving all of life on earth on the other. It should be appreciated that there was nothing unusual about either Ratzel's assumption that human society and politics were subject to the same natural laws as the animal and plant kingdoms or his view of the political state as a biological organism. ${ }^{23}$ Indeed, his essay originally appeared in a festschrift honoring the sociologist and political economist Albert Schäffle, whose own four-volume Bau und Leben des Socialen Körpers was comprehensive presentation of the unity of social and biological processes. ${ }^{24}$ Ratzel's Politische Geographie did make a distinctive contribution to this perspective, namely the insistence that the state-organism was bodenständig, that is to say a bio-geographical and territorial organism with deep roots in the earth and soil. ${ }^{25}$ With his Lebensraum concept he began to demonstrate more specifically how the biological imperative for migration and colonization described by his mentor Wagner was manifested in the contemporary world in the form of an inexorable political imperative for state growth and territorial expansion. 
As noted above, Ratzel did not develop the Lebensraum concept until relatively late in his intellectual career, and beyond the essay presented here he actually used the term very little. ${ }^{26}$ Nevertheless, his work was an essential catalyst, and in the years following his death its proliferation was rapid. The historian Fritz Fischer has argued that by 1914 Lebensraum was already a key inspiration behind the plans for territorial annexation and resettlement set out in the Septemberprogramm as Germany's primary war aims. ${ }^{27}$ Yet while the term itself appears not to have been used during the First World War, after 1918 Lebensraum quickly came into broad currency, and indeed in a variety of connections. Ratzel's fellow biologists and biogeographers immediately appreciated the naturalist underpinnings of his argument, and they began to use the term in their analyses of the ecological relationship between organisms and their habitats. ${ }^{28}$

Far more striking, however, was its rapid penetration into political discourse. At the end of the war, Germany lost not only all of its overseas colonies but significant territories in Europe itself. The perception of space-deprivation and a pressing Raumbedarf - or need for more territory to accommodate Germany's growing population - which was palpable already in Ratzel's day, grew ever more widespread and acute. Germany's space crisis was a central concern for the new discipline of Geopolitik, which developed a broad profile in the 1920 s thanks largely to the efforts of the retired Bavarian general Haushofer. The term Geopolitik had been coined in the late 1890 s by the Swedish political scientist Rudolf Kjellen, but it was Ratzel's environmentalist politische geographie and his notion of Lebensraum that provided Haushofer's organizing framework. ${ }^{29}$ Howver, as David Murphy has documented, the issue of Lebensraum was not restricted to the geopoliticians. ${ }^{30}$ It became a prominent keyword across a variety of academic disciplines in this period, and it also resonated powerfully on more popular levels. The writer Hans Grimm captured this obsession in his hugely popular novel Volk ohne Raum, which sold far more copies than any work of Haushofer's. ${ }^{31}$

This broad proliferation of the Lebensraum concept demonstrated an essential quality of the term, namely its considerable plasticity and ability to mean different things in different contexts for different people. Thus, while Ratzel himself had intended the subject of the Lebensraum imperative to be the political state conceived as a biological organism, in the 1920 s this was sometimes modified — as Grimm's title suggests - to make the people or Volk the subject instead. This shift was related to a more general inter-war concern with ethnicizing territory, apparent for example in the Volksboden notion developed by Albrecht Penck and others. ${ }^{32}$ At the same time, the notion of Lebensraum crossed lines with interests in the model of a Wirtschaftsraum or Grosswritschaftsraum as a self-contained space for the development of a highly-planned and autarkic economy. ${ }^{33}$

Although these elaborations on the Lebensraum idea were quite different, their departures from the original Ratzelian sense of the term share important similarities. Lebensraum in both cases is conceived not as a naturally given area controlled by natural laws, but rather as an anthropogenic space that could be created, deliberately and methodically, through the extension of political boundaries, the rearrangement of populations and the reshaping of the landscapes themselves, all effected through rational planning and efficient administration. In both cases, moreover, the geographical locus of attention was extended to include not only the extra-European colonial spaces that Ratzel himself had focused on but European territory itself, above all spaces to the east of Germany.

Most significant, of course, was the appeal of the Lebensraum concept for the Nazi movement. ${ }^{34}$ From a variety of standpoints, it suited their purposes perfectly. It captured quite neatly the spirit of their political programme of territorial expansion and conquest, and helpfully legitimized this programme by characterizing it as a natural and organic imperative necessary for the healthy growth of the German nation. On a more theoretical level, the biological foundations of Ratzelian Lebensraum corresponded with their own biopolitical understanding of the dynamics of world affairs. ${ }^{35}$ Already in the early 1920s, Adolf Hitler used the term repeatedly in his manifesto Mein Kampf to describe and justify his call for Germany to 
reclaim the territories it had lost in the war and expand beyond them. The National-Socialist movement, he declared, 'must find the courage' to lead the German people 'out of the confinement of their [current] Lebensraum to new lands', thereby enabling the 'disproportion between the size of our population and the extent of our territory' to be rectified. ${ }^{36}$ For Hitler, Germany's potential Lebensraum would be secured both within Europe and across the globe, a perspective clearly reflected in the Stufenplan strategy followed during the Second World War. ${ }^{37}$

Even for the Nazis, however, the appeal of Lebensraum depended on the term's semantic elasticity, and they used the term in different and contradictory ways. The connection noted above between Lebensraum and Volk - rather than the state - was reemphasized and designated specifically as a correlation between land and race. This organic connection was at the centre of the ruralist and pastoral Blut und Boden doctrine promoted by Heinrich Himmler, Richard Darré and other leading Nazis..$^{38}$ But the notion of Lebensraum as a space of anthropogenic construction was maintained, and indeed took on a new urgency after the outbreak of war, as Germany's conquests in Eastern Europe began to make territory available for these purposes. Across these spaces, Lebensraum was to be created through a deliberate step-by-step process, beginning with population transfer and ethnic cleansing, followed by German agricultural colonization and the reconstruction of cultural landscapes as genuine German Lebensräume. ${ }^{39}$

After 1945, the concept of Lebensraum, along with geopolitics more generally, was fundamentally discredited by virtue of this close association with the Nazi regime. Somewhat paradoxically, however, it was at this moment, and with this discreditation, that the term began to enter common usage in Anglo-American discourses where it remains today a familiar term of reference. Its connotations vary considerably, but are always and uniformly negative: a reductionist view of nations and states as biological entities, the advocacy of imperialist expansion, the urge to hegemonic domination and control, ethnic cleansing and even genocide. The fact that the term is a German-language word ensures that it always evokes a pejorative undertone of reference back to Nazi fascists. With these associations, Lebensraum is used quite commonly to characterize policies and actions of states that are seen to be aggressive and, particularly, territorially aggrandizing toward their neighbors. Deployed in this sense, the scope of the term is unlimited, and it is used freely in critical reference to states across the globe whose circumstances and policies in fact differ considerably, including China, Poland, Russia, Israel and the United States..$^{\circ}$

But the spirit of Ratzel's original Lebensraum idea has survived nonetheless. During World War II, it was Isaiah Bowman, the American geographer who was later an advisor to Franklin D. Roosevelt, who sought to sanitise the term Lebensraum and save it from its usage by the Nazis. ${ }^{41}$ As he claimed in a famous essay, "There is virtue in the argument of "organic boundaries" and the philosophy of Lebensraum, but they are open to abuse'. ${ }^{22}$ In Cold War West Germany, civil defence planners continued to use the term Lebensraum to argue for new subterranean living spaces, bunkers that would enable West Germany to survive a nuclear war on its territory. ${ }^{43}$ In Latin America, many of the ideas of German Geopolitik had already been taken up in the interwar period. After the war, military and political elites in many of these countries continued to be inspired by the vision of redesignating political boundaries and augmenting national territories to accommodate and facilitate the 'natural' growth of their respective states. Spanish and Portuguese translations of Ratzel and Haushofer found enthusiastic audiences, and Ratzel's conceptualization of Lebensraum provided an appealing rationale and legitimation for projects of expansion and national development. ${ }^{44}$ More recently, the Turkish politician Ahmet Davutoglu, who served as prime minister from 20142016, steeped himself in the geopolitical teachings of Ratzel and Haushofer and advanced policies based on these ideas. Seeking to realize a neo-Ottoman and pan-Islamic vision for his country's future, Davutoglu spoke openly of Turkey's need to establish hegemony over its geographical 'hinterland' (the Caucasus, Balkans and the Middle East) and to carve out a new 
Lebensraum which would be the basis for the eventual cultural and economic integration of the Islamic world. 45

Finally, post-Soviet Russia offers a particularly vivid example of the dynamism of contemporary Lebensraum discourse. Since the collapse of the Soviet Union in the early 1990s, classical geopolitical theories from the West - and in particular from German Geopolitik have attracted broad interest as an appealing explanatory perspective to take the place of a discredited Marxism-Leninism. The most visible advocate of this neo-classical geopolitics is Aleksandr Dugin, whose enthusiasm for Ratzel was noted above. Dugin's magnum opus The Fundamentals of Geopolitics includes extensive discussions of Ratzel, Haushofer and the concept of zhiznennoe prostranstvo or Lebensraum. ${ }^{46}$ In Haushofer's understanding of the term, he claims, there was no inherent hostility to Russia, and certainly nothing 'anti-Slavic'. ${ }^{47}$ Currently an influential political analyist and media commentator, Dugin is an unabashed advocate of expanding Russia's regional hegemony and territorial control. He strongly supports both Russia's annexation of Crimea and incursion into eastern Ukraine as well as the creation of the Eurasian Economic Union, seeing all of these activities as moves to secure and enhance a Russian Lebensraum of the future. $4^{8}$

\section{Discussing Lebensraum}

This special section of the Journal of Historical Geography brings together an interdisciplinary group of geographers, historians and political scientists to reflect on the first full translation of Ratzel's 1901 essay on Lebensraum. Although the concept of Lebensraum has long been crucial to the history of the geographical discipline, this seminal text was so far accessible to readers of German only. We will begin with a note by the essay's translator, Tuesday (Tul'si) Bhambry, which speaks to the linguistic and political intricacies of translating Ratzel in the twenty-first century. In what follows, the historian Ulrike Jureit seeks to contextualise Ratzel's essay within Wilhemine imperialism. She argues that Ratzel functions as a transitional figure who links nineteenth-century imperial thinking with a twentieth-century drive towards expansion and extermination. In a subsequent essay, David Murphy, another historian, illuminates the trajectory of the Lebensraum concept from Ratzel's initial formulation through its proliferation in the interwar period and down to its role in the Third Reich's conquest and colonisation of Eastern Europe. In the third essay, the political scientist Patricia Chientera-Stutte makes sense of Ratzel through the lens of biopolitics, focusing in particular on his concepts of nature and culture. Ian Klinke, a political geographer, picks up this thread in his contribution as he explores death as a crucial leitmotif in both the Lebensraum essay and Ratzel's ouvre more generally. Finally, the animal geographer Maan Barua poses critical questions about the affinities of contemporary more-than-human geography and Ratzel's work. Investigating Ratzel not as a political but as a biogeographer, he unpacks the spatial ontologies of animal life articulated in the Lebensraum essay.

Taken together, this translation and the subsequent commentaries aim to give new impetus to ongoing debates in geography and beyond that have addressed inter alia the history of biopolitics, theories of nature/society relations, geopolitics and colonial thinking as well as the interface of geography and social Darwinism, broadly conceived. Most of all, we wish to reignite a scholarly interest in Friedrich Ratzel that ventures beyond Ratzel's now well-known territorial fetish to explore the diverse web of often rather outlandish ideas that he had come to promote by the turn of the previous century. This seems a particularly pressing task given the stealthy influence Ratzel had on a wide variety of political thinkers that came to shape the $20^{\text {th }}$ century in different ways. Ultimately, we hope that readers will find new patterns and interpretations in the rich, vibrant and sometimes obscure tapestry of the Lebensraum essay. 
${ }^{1}$ A. Hitler, Mein Kampf, Munich, 1943. Haushofer was introduced to Hitler by Rudolf Hess, Haushofer's former student and friend who had become Hitler's right-hand man and was incarcerated with him in Landsberg prison while Mein Kampf was being written. Haushofer claimed that he brought with him a copy of Ratzel's Politische Geographie and introduced the Lebensraum concept to Hitler. See K. Haushofer, Friedrich Ratzel als raum- und volkspolitischer Gestalter, in Friedrich Ratzel. Erdenmacht und Völkerschicksal. Eine Auswahl aus seinen Werken, Stuttgart, 1940, ix-xxvii; Peter Ross Range, 1924: The Year That Made Hitler, New York, 2016; see also T. Barnes and C. Abrahamsson, Tangled complicities and moral struggles: the Haushofers, father and son, and the spaces of Nazi geopolitics, Journal of Historical Geography 47 (2015) 64-73.

2 T. Lemke, Biopolitics: An Advanced Introduction, New York and London, 2011, 13.

3 S. Whatmore, Materialist returns: practicing cultural geography in and for a more-than-human world, Cultural Geographies 13 (2006) 600-609.

4 G. Buttmann, Friedrich Ratzel: Leben und Werk eines deutschen Geographen, Stuttgart, 1977, 35; G.H. Müller, Friedrich Ratzel (1844-1904), Naturwissenschaftler, Geograph, Gelehrter, Stuttgart, 1996; J. Steinmetzler, Die Anthropogeographie Friedrich Ratzels und ihre ideengeschichtlichen Wurzeln, Bonn, 1956; H. Wanklyn, Friedrich Ratzel: A Biographical Memoir and Bibliography, Cambridge, 1961.

5 M. Bassin, Imperialism and the nation state in Friedrich Ratzel's political geography, Progress in Human Geography 11 (1987) 473-495; U. Jureit, Das Ordnen von Räumen: Territorium und Lebensraum im 19. und 20. Jahrhundert, Hamburg, 2012.

6 D.T. Murphy, Heroic Earth: Geopolitical Thought in Weimar Germany, 1918-1933, London, 1997; G.Ó. Tuathail, Critical geopolitics: The politics of writing global space, Minneapolis, 1996; N. Werber, Geopolitik zur Einführung, Hamburg: 2014 .

7 C. Abrahamsson, On the genealogy of lebensraum, Geographica Helvetica 68 (2013) 37-44; M. Halas, Searching for the perfect footnote: Friedrich Ratzel and the others at the roots of Lebensraum, Geopolitics, 19 (2014), 1-18; W. Smith, Friedrich Ratzel and the origins of Lebensraum, German Studies Review 3 (1980), 51-68.

${ }^{8}$ For exceptions see F. Ratzel Sketches of urban and cultural life in North America, New Brunswick and London, 1876[1988]; F. Ratzel, The history of mankind, Volume I, London, 1885[1896] (see also vol. II and III); F. Ratzel, The territorial growth of states, in: J. Agnew, D. Livingstone and A. Rogers (eds.) Human Geography: An essential Anthology, Oxford, 1896[2005], 527; F. Ratzel, Studies in political areas. The political territory in relation to earth and continent, American Journal of Sociology 3 (1897), pp. 297-313.

9 T. Barnes and C. Minca, Nazi spatial theory: The dark geographies of Carl Schmitt and Walter Christaller, Annals of the Association of American Geographers 103 (2013), 669-687; S. Legg, Spatiality, sovereignty and Carl Schmitt: Geographies of the nomos, London, 2011; C. Minca and R. Rowan, On Schmitt and space, London, 2015.

${ }^{10}$ C. O. Sauer The formative years of Ratzel in the United States, Annals of the Association of American Geographers 61 (1971) 245-254.

${ }^{11}$ F. Ratzel, Die Erde und das Leben, 2. Band. Leipzig und Wien: 1902, 543.

${ }^{12}$ F. Ratzel, Glücksinseln und Träume: Gesammelte Aufsätze aus dem Grenzboten, Leipzig: 1905, 139.

${ }^{13}$ Friedrich Ratzel, Das Meer als Quelle der Volkergrössse, 2nd ed., Munich, 1911; Bassin, Imperialism and the nation state.

${ }_{14}$ F. Ratzel, Nationalitäten und Rassen, in H. Helmolt, Kleinere Schriften von Friedrich Ratzel, herausgegeben von Hans Helmolt, 2. Band. München, 1906, 462-487.

15 K.-H. Weißmann, Rubikon: Deutschland vor der Entscheidung, Berlin: 2016.

${ }^{16}$ M. Laruelle, The two faces of contemporary Eurasianism: an imperial version of Russian nationalism, Nationalities Papers 32 (2004), 128.

17 Buttmann, Friedrich Ratzel, 110.

${ }^{18}$ O. Peschel, Völkerkunde, Leipzig, 1874: 21, 58, 85, 397; also see O. Peschel, Ursprung und Verschiedenheit der Menschenrassen, Das Ausland 33 (1860): 393.

19 R. Andree, Zur Volkskunde der Juden, Bielefeld/Leipzig, 1881: 1-3, 7, 24.

${ }^{20}$ T.R. Malthus, An Essay on the Principle of Population, 6th ed., London, 1826: 95, 93, 7.

${ }^{21} \mathrm{M}$. Halas, Searching for the perfect footnote: Friedrich Ratzel and the others at the roots of lebensraum, Geopolitics 19, no. 1 (2014): 1-18, here 7.

${ }^{22}$ Also see K.-G. Faber, Zur Vorgeschichte der Geopolitik. Staat, Nation, und Lebensraum im Denken deutscher Geographen vor 1914, in Weltpolitik, Europagedanke, Regionalismus. Festschrift für Heinz Gollwitzer zum 65. Geburtstag., ed. Heinz Dollinger, Horst Gründer, and Alwin Hanschmidt, Münster, 1982: 389-406.

${ }_{23}$ O. Hertwig, Die Lehre von Organismus und ihre Beziehung zur Sozialwissenschaft, Jena, 1899.

24 A. Schäffle, Bau und Leben des Socialen Körpers, 4 vols., Tübingen, 1875-78.

${ }_{25}$ F. Ratzel, Politische Geographie, oder die Geographie der Staaten, des Verkehrs, und des Krieges, Munich and Leipzig, 1897.

${ }^{26}$ The first mention of Lebensraum was in 1897: F. Ratzel, Über den Lebensraum, Die Umschau 1:21 (1897): 363-367. Also see F. Ratzel, Anthropogeographie, 3rd ed., 2 vols., Stuttgart, 1909, Volume. 1: 149-150; Friedrich Ratzel, Zur Frage der Indogermanen-Heimat, Archiv für Rassen- und Gesellschafts-Biologie 1: 4 (1904): 579-580;

${ }_{27}$ F. Fischer, Griff nach der Weltmacht: die Kriegszielpolitik des kaiserlichen Deutschland, 1914-1918, Dusseldorf, 1961. 
${ }^{28}$ E.g. H. Gams, Prinzipienfragen der Vegetationsforschung, Vierteljahrsschrift der Naturforschenden Gesellschaft in Zürich 63 (1918): 293-493; F. Peus, Beiträge Zur Kenntnis der Tierwelt nordwestdeutscher Hochmoore. Eine ökologische Studie..., Zeitschrift für Morphologie Und Ökologie der Tiere 12:3/4 (1928): 533-683

29 On the history of Geopolitik see F. Ebeling, Karl Haushofer und seine Raumwissenschaft 1919-1945, Berlin, 1994; R. Sprengel, Kritik der Geopolitik. Ein deutscher Diskurs, 1914-1944, Berlin, 1996; B. Hipler, Hitlers Lehrmeister. Karl Haushofer als Vater der N-S Ideologien, St. Ottilien, 1996; D. T. Murphy, The Heroic Earth. Geopolitical Thought in Weimar Germany, 1918-1933, Kent OH, 1997.

$3^{\circ}$ In addition to his essay in this collection see Murphy, Heroic Earth.

${ }^{31}$ H. Grimm, Volk ohne Raum, Munich, 1926; Murphy, Heroic Earth.

${ }^{32}$ A. Penck, Deutscher Volks- und Kulturboden, in Volk unter Völkern, ed. K.C. von Loesch, Breslau, 1925: 62-73.

33 H. Kahrs et al., eds., Modelle für ein deutsches Europa. Ökonomie und Herrschaft im Großwirtschaftsraum, Berlin, 1992.

34 W. D. Smith, The Ideological Origins of Nazi Imperialism, New York, 1986; I. Kamenetsky, Secret Nazi Plans for Eastern Europe: a Study of Lebensraum Policies, New York, 1961; M. Housden, Hans Frank: Lebensraum and the Holocaust, New York, 2003; K. Uhl, The ideal of Lebensraum and the spatial order of power at German factories, 1900-45, European Review of History: Revue europeenne d'histoire 20, no. 2 (2013): 287-307.

35 Halas, Searching for the perfect footnote,: 15.

${ }^{36}$ Hitler, Mein Kampf , 732 (quote), 148, 164, 165, 333, 334. For discussions of Hitler and Lebensraum see K. Lange, Der Terminus 'Lebensraum' in Hitlers Mein Kampf, Vierteljahresheft für Zeitgeschichte 13:4 (1965): 426-437; R. Binion, Hitler's concept of 'Lebensraum': the psychological basis, The Journal of Psychohistory 1: 2 (1973): 187-258. 37 A, Hillgruber, Hitlers Strategie : Politik und Kriegführung 1940-1941, 3rd ed., Bonn, 1993; I. Kershaw, The Nazi Dictatorship: Problems and Perspectives of Interpretation, London, 2015.

${ }^{8}$ A. Bramwell, Blood and soil. Richard Walther Darré and Hitler's Green Party, Bourne End, 1985; G. Corni and H. Gies, "Blut und Boden." Rassenideologie und Agrarpolitik im Staat Hitlers, Idstein, 1994; M. Bassin, Blood or soil? The volkisch movement, the Nazis, and the legacy of Geopolitik, in How Green Were the Nazis? Nature, Environment, and Nation in the Third Reich, ed. F.-J. Brüggemeier, M. Cioc, and T. Zeller, Athens OH, 2005: 204-242; P.

Zimmermann, Kampf um den Lebensraum. Ein Mythos der Kolonial-und der Blut-und-Boden-Literatur, in Die Deutsche Literatur im Dritten Reich : Themen, Traditionen, Wirkungen, ed. H. Denkler and K. Prümm, Stuttgart: 165182.

39 W. Lower, A new ordering of space and race: Nazi colonial ereams in Zhytomyr, Ukraine, 1941-1944," German Studies Review 25: 2 (2002): 227-254; P. W. Blood, Securing Hitler's Lebensraum : The Luftwaffe and Białowieża Forest, 1942-1944, Holocaust and Genocide Studies 24:2 (2010): 247-272.

$4^{\circ}$ P. Bowring, Lebensraum and China, Asia Sentinel 20 September (2012),

http://www.asiasentinel.com/politics/lebensraum-and-china/, accessed on 2/11/2017; B. Balogun, Polish Lebensraum: the colonial ambition to expand on racial terms, Ethnic and Racial Studies (2017): 1-19; T. MonroeHamilton, Putin adopts a Russian Lebensraum policy," NoisyRoom.net 27 February (2014),

http://noisyroom.net/blog/2014/o2/27/putin-adopts-a-russian-lebensraum-policy/, accessed on 2/11/2107; Y. Sarid, "Lebensraum as a justification for Israeli settlements," Haaretz 26 August (2011),

https://www.haaretz.com/lebensraum-as-a-justification-for-israeli-settlements-1.380787, accessed on 2/11/2017; J. McMurtry, "Ukraine, America’s 'Lebensraum'. Is Washington preparing to wage war on Russia?," Global Research 13 March (2016), https://www.globalresearch.ca/ukraine-americas-lebensraum-is-washington-preparing-to-wage-waron-russia/5431970, accessed on 4/2/2107.

${ }^{41}$ N. Smith, American Empire: Roosevelt's Geographer and the Prelude to Globalization, Oakland: $2004,319$.

${ }^{42}$ I. Bowman, Geography vs. geopolitics, Geographical review, 32 (1942), 646-658, 653.

43 I. Klinke, Cryptic Concrete: A Subterranean Journey into Cold War Germany, Oxford, 2018.

44 J. Child, Antarctica and South American Geopolitics: Frozen Lebensraum, Westport CN, 1988; J. Child, 'Latin Lebensraum': the geopolitics of Ibero-American Antarctica, Applied Geography 10: 4 (1990): 287-305; A. Rivarola Puntigliano, Geopolitics of integration' and the imagination of South America, Geopolitics 16, no. 4 (2011): 846-864. 45 A. Stein, Turkey's New Foreign Policy: Davutoglu, the AKP and the pursuit of regional order, RUSI Whitehall Paper 83 (2014); B. Ozkan, Turkey, Davutoglu and the idea of pan-Islamism, Survival 56:4 (2014): 119-140; B. Ozkanaug, Turkey's imperial fantasy, New York Times 28 August (2014), https://www.nytimes.com/2014/o8/29/opinion/ahmetdavutoglu-and-turkeys-imperial-fantasy.html? r=0, accessed on 2/11/2017.

${ }^{46}$ A.G. Dugin, Osnovy geopolitiki. Geopoliticheskoe budushchee Rossii, 1st ed., Moscow, 1997.

47 http://propagandahistory.ru/books/Aleksandr-Dugin_Konspirologiya/179.

${ }^{8}$ A.G. Dugin, Proekt 'Evraziia'. Geografiia--nasha sub'ba, Moscow, 2004; A. Barbashin and H. Thoburn, Putin's brain: Alexander Dugin and the philosophy behind putin's invasion of Crimea, Foreign Affairs 31 (2014), at https://www.foreignaffairs.com/articles/russia-fsu/2014-03-31/putins-brain, accessed on 2/11/2017. 